\title{
Peruanos y bolivianos en la sátira chilena de la Guerra del Pacífico (1879-1884)
}

\author{
Patricio IbARra Cifuentes \\ Universidad Bernardo O'Higgins \\ patricio.ibarra@ubo.cl
}

Recibido: 1 de octubre de 2015

Aceptado: 12 de febrero de 2016

\begin{abstract}
Resumen
A partir de los grabados publicados en las páginas de los periódicos que incluyeron humor gráfico en sus ediciones durante la Guerra del Pacífico (1879 - 1883), los caricaturistas chilenos desplegaron un discurso visual agresivo en clave patriótica y belicista, donde presentaron a sus lectores una imagen crítica y despectiva respecto de los adversarios de Chile. Recalcaron la supuesta falta de ánimo y valor combativo, ante la sola presencia de los efectivos militares chilenos tanto en el mar como en tierra. Así, la tinta y el papel, se transformaron en otra de las armas que intervinieron en el conflicto de Chile contra el Perú y Bolivia por la posesión de los ricos territorios salitreros de Tarapacá y Antofagasta. Las imágenes fueron interpretadas a partir de los postulados de la Escuela de Warburg, en especial los de Erwin Panofsky, que propone tres niveles de estudio del significado de cada obra, a saber, la "descripción preiconográfica", luego el "estudio iconográfico" en cuanto tal y, finalmente, la "interpretación iconológica".
\end{abstract}

Palabras clave: Guerra del Pacífico; Caricaturas; Prensa Satírica; Historia de los medios de comunicación.

\section{"All allies play dead": Peruvians and Bolivians in Chilean War of the Pacific's cartoons (1879-1883)}

\begin{abstract}
From the engravings published in the pages of newspapers that included humor in its editions during the Pacific War (1879 - 1883), Chilean cartoonists deployed an aggressive visual speech patriotic and bellicose key, where they presented their readers a contemptuous criticism and respect of opponents of Chile's image. They stressed the alleged lack of fighting spirit and courage, by the mere presence of Chilean troops both at sea and on land. Thus, the ink and the paper, became another of the weapons involved in the conflict in Chile against Peru and Bolivia for possession of the rich nitrate territories of Tarapaca and Antofagasta. The images were interpreted from the postulates of the School of Warburg, especially Erwin Panofsky, proposed three levels of study of the meaning of each work, namely the "preiconographic description", then the "iconographic study" and finally "iconological interpretation".
\end{abstract}

Keywords: War of the Pacific; Cartoons; Satiric Press; Media History. 


\section{Referencia normalizada}

Ibarra Cifuentes, P. (2016). Peruanos y Bolivianos en la sátira chilena de la Guerra del Pacífico (18791884). Historia y Comunicación Social. Vol 21, número 1, páginas 75-95.

Sumario: 1. Introducción. 2. Las caricaturas y los enemigos de Chile durante la Guerra del Pacífico. 3. Los aliados Perú-bolivianos en los periódicos chilenos de caricaturas durante la Guerra del Pacífico. 4. Conclusión. 5. Referencias bibliográficas.

\section{Introducción.}

El estallido de la Guerra del Pacífico, también conocida como Guerra del Salitre, en febrero de 1879 , provocó que la atención de la sociedad chilena se centrara en el conflicto que enfrentaría al país contra sus vecinos septentrionales. Los chilenos se dirigirían al norte para combatir la alianza que unía peruanos y bolivianos, en el marco de la disputa por la posesión de los ricos territorios salitreros de Antofagasta y Tarapacá. Naturalmente, los medios de prensa contemporáneos volcaron sus recursos para informar y comentar los hechos que se producían tanto con las negociaciones diplomáticas, así como en el frente de batalla. De ese modo, gran parte del espacio dedicado a las noticias de actualidad se consagró a cubrir las alternativas del conflicto en desarrollo, a través de las crónicas de los corresponsales de guerra, notas, columnas de opinión y la publicación de diversos documentos relacionados con la conflagración.

El inicio de las hostilidades implicó que se estimulara la sensibilidad colectiva de las sociedades de los países beligerantes, en torno a procesos que definieron su unidad como nación. Así fue como la Guerra del Pacífico se transformó en una instancia paradigmática, donde el sentimiento patriótico popular y el nacionalismo estatal convergieron para integrar y consolidar la imagen del enemigo a enfrentar y derrotar. A partir de aquello, en Chile proliferaron diversas manifestaciones artísticas (plásticas y literarias) en distintos formatos, que dieron cuenta de ese estado de cosas, a través de un discurso que hizo hincapié en fortalecer la identidad propia, además de diferenciarse material y culturalmente de los enemigos Perú - bolivianos (Donoso Huidobro, 2015: 78 - 80).

Una de las expresiones plásticas fueron las caricaturas publicadas en los periódicos de sátira chilenos, que se transformaron en vehículo interpretativo de apreciaciones y expectativas respecto de la guerra en desarrollo, además de modelar ideas y percepciones, e incidir de manera concreta en el conocimiento de la población lectora de noticias de los personajes y hechos vinculados a la guerra (Ibarra, 2013: 60 - 62).

Desde el inicio del conflicto, en los diarios chilenos se desplegó una retórica y discurso agresivo, en clave patriótica y belicista caracterizada por el intento de vituperar instituciones, cultura, población y actuar de los adversarios de Chile. (Rubilar, 2011: 72 - 74). A ello debe sumarse, que la necesidad de enfrentar el conflicto con un sentido unitario y el intento de diferenciación cultural con los adversarios, significó 
la creación de estereotipos de peruanos y bolivianos, por cuanto se convirtieron un "otro" al cual había que someter o aniquilar. Asimismo, esa manera de caracterizar a los vecinos del norte adquirió también rasgos racistas. (Arellano, 2012: 258, Arellano, 2014: 396).

En torno a ese eje se condujo el debate de ideas la Opinión Pública chilena respecto de la imagen construida de los enemigos de Chile durante los años de la Guerra del Pacífico, donde los editores de los periódicos "definieron lo público como instancia de socialización y mediación de lo individual y al mismo tiempo confeccionaron un mapa cognitivo de la guerra que Chile enfrentaba con sus vecinos". Asimismo, la prensa actuó como "centro de noticias, organizadora de múltiples rituales patrióticos, integradora de valores divergentes, tribuna del pueblo, una veces consejera y otra crítica del gobierno, además de núcleo de una retórica republicano - nacionalista". (Mc Evoy, 2011: 138 - 139). Todo aquello en el contexto de tolerancia temática y de contenidos otorgada por la libertad de prensa consagrada por la ley de 1872 (Ibarra, 2014: 311).

La prensa que incluyó grabados satíricos en sus ediciones, profundizó esa forma de cubrir las alternativas de la guerra. Tanto en sus editoriales, artículos, versos y, especialmente en sus caricaturas. Peruanos y bolivianos fueron presentados como un enemigo que debía ser derrotado, merced a su condición intrínsecamente inferior a la del chileno. En ese sentido, la estrategia periodística de los editores de los periódicos de humor gráfico, fue similar a la de sus pares de noticias. Empero, merced a las características propias de su lenguaje, la sátira escrita y visual, les permitió presentar una representación más caustica y despectiva de los adversarios de Chile.

Los rotativos de caricaturas editados en Chile presentaron estereotipos negativos respecto de peruanos y bolivianos a sus lectores. Un patrón destacado de esa representación, el que se presentará en las páginas que vienen, fue su caracterización como temerosos, débiles, faltos de valor moral y coraje, además del menosprecio respecto de su potencial militar como adversario, plasmados en su supuesto temor al momento de enfrentarse a los chilenos en el campo de batalla. Más importante aún, aquello intentó trasuntar la aparente debilidad de las convicciones y compromiso nacional de los aliados, en comparación al de los chilenos, que por contraposición, se elogiaba y dejaba en alto, al igual como ocurría en otras expresiones artísticas tales como el teatro contemporáneo a la guerra (Donoso - Huidobro, 2015: 91).

En ese contexto, un ícono relevante fue el del roto, representación metafórica del hombre del bajo pueblo chileno, cuyo comportamiento en las filas del ejército fue ensalzado durante los años de guerra por la prensa y la opinión pública (Cid, 2009: 221 - 254); el cual fue utilizado por editores y caricaturistas contraponiéndolo simbólicamente a peruanos y bolivianos. Según Peter Burke, la creación de estereotipos como esos y su proliferación masiva no solo obedece a la voluntad del autor de una imagen, en este caso caricaturas, sino también a los deseos voyeuristas de quienes las observan (Burke, 2001: 155 - 175). Así entonces, los dibujantes chilenos, Benito Basterrica y especialmente Luis Fernando Rojas, al crear nuevas formas pictóricas 
alusivas a peruanos y bolivianos, recogieron e interpretaron muchas de las ideas, nociones y prejuicios prexistentes entre los chilenos al momento del estallido de la conflagración.

De esa manera, las imágenes presentadas por los rotativos de sátira eran, en parte, también la materialización de la rivalidad e ideas de superioridad afincadas en la sociedad chilena respecto de sus vecinos del norte, incubadas por décadas antes al conflicto de 1879. (Collier, 2005: 197 - 200). Esas opiniones se fortalecieron por la dinámica de lo que Lawrence LeShan denominó, "Guerra mítica", caracterizada por la participación transversal de la sociedad en el esfuerzo de la lucha, la aparición de héroes populares, una excitación general por conocer y participar de los encuentros armados, además de la idea de formar parte de una cruzada contra el mal, entre otras percepciones. Todo aquello en el contexto de la mentalidad del cuerpo social decimonónico finisecular (Le Shan, 1992: 77).

A través de las imágenes, del humor, la exageración y la incorrección política, los editores de los periódicos y los caricaturistas enseñaron a los observadores de sus obras su visión respecto de los enemigos de Chile en la Guerra del Pacífico. Así, el acoso burlesco, similar al desplegado contra la élite contemporánea, a saber: políticos, funcionarios del gobierno, dignatarios de la Iglesia, capitalistas, entre otros, propio de las querellas gatilladas por el día a día del quehacer público y la disputa por el control de la administración del Estado, se manifestó con mayor crudeza contra peruanos y bolivianos (Salinas, 2006: 235 - 236). Empero, se trató de un acorralamiento satírico sin respuesta, pues los aliados difícilmente tendrían acceso en Chile a algún medio de comunicación o instrumento político con el cual responder a los ataques. En definitiva, ese discurso, adquirió características de monólogo funcional para los tiempos de guerra, en tanto en la sociedad chilena existió un consenso transversal y mayoritario, respecto de la necesidad y justicia de la consecución de un triunfo ante sus vecinos del norte (Mc Evoy, 2011: 138 - 149).

En las páginas que vienen a continuación se expondrán los grabados publicados en los periódicos El Barbero, El Nuevo Ferrocarril, El Ferrocarrilito y El Padre Cobos todos ellos editados en Santiago, cuyos dibujos dedicados a caracterizar a peruanos y bolivianos como carentes de valor frente a los chilenos, vieron la luz pública entre 1879 y 1883 . Se utilizarán estos rotativos, pues sus ediciones permiten cubrir los cuatro años de guerra, dando cuenta de modo general la manera en que la representación irónica de los enemigos de Chile, estuvo presente durante todo el conflicto, desde su inicio en febrero de 1879 hasta sus últimas operaciones militares en 1883 . Además, dos de ellos, El Ferrocarrilito y El Padre Cobos, son de los más importantes rotativos de caricaturas del periodo, tanto por su duración temporal 1880 - 1881 y 1881 - 1885 respectivamente (Donoso, 1950 y Briseño, 1987), como por la participación en ellos de Juan Rafael Allende, célebre publicista y editor de periódicos de sátira liberal de fines del siglo XIX (Salinas, 2005; Salinas, 2006; Salinas, et. al. 2011; Cornejo, 2006a; Ibarra, 2013). Del mismo modo, contaron con la participación de Luis Fernando Rojas, uno de los más representativos ilustradores de fines del siglo XIX y comienzos del XX en Chile (Ureta y Álvarez, 2014). 
Así, el análisis de la iconografía presente en los periódicos señalados, permite acercarse a documentos que dan cuenta un fenómeno histórico, en este caso cómo se representó a los enemigos de Chile durante su guerra contra la alianza formada por el Perú y Bolivia entre 1879 y 1884, desde una perspectiva diferente pues esos dibujos permiten acceder a un relato gráfico, "rico en interpretaciones y gracias al cual se pueden conocer nuevas perspectivas" (Sola y Barroso, 2014: 244).

En ese sentido las caricaturas chilenas de la Guerra del Pacífico, se constituyen en una emanación material (imagen) de como se representó, imaginó y conoció de un conflicto, de manera icónica y simbólica, cuyas alternativas se registraron a miles de kilómetros de los grandes centros poblados. Los dibujantes y editores de los periódicos canalizaron la representación despectiva de los adversarios de Chile, materializándolos individuos concretos (dirigentes y jefes militares), en símbolos de la generalidad de la población civil no combatiente y en acciones concretas (batallas y acciones militares). Así fue como la caricatura se transformó en un producto externo a la guerra en cuanto tal, que colocó en la conciencia de quienes las observaron las imágenes preconcebidas creadas por editores y dibujantes de la prensa de sátira contemporánea (Gimate -Welsh, 2011: 64 - 65). Aquello giró en torno a la recuperación y exageración de ideas preconcebidas y a partir de ellos la exposición de juicios negativos respecto de peruanos y bolivianos durante los años del conflicto. Así, al reiterar la idea de la cobardía como una característica intrínseca de los aliados Perú - bolivianos, permitió la creación de un modelo de conducta estereotipado de ellos y la diferenciación respecto de los chilenos. Siguiendo la propuesta de Homi Bhabha en su libro El lugar de la cultura, relativos a la instauración de un nuevo régimen de verdad a partir de la fijación de una determinada representación de un "otro", visibilizado y rechazado a la vez a consecuencia de la repetición de un estereotipo (Bhabha, 2002: 92, 108), se puede se afirmar en este caso que la idea relacionada con la cobardía de peruanos y bolivianos, y por extensión la superioridad de los chilenos, resultó conveniente para la unificación de un discurso patriótico - nacionalista que reforzó la cohesión en torno al esfuerzo bélico desplegado entre 1879 y 1884 . De paso, sirvió para atraer mediante su discurso y retórica visual de trinchera, a sus lectores, como una estrategia más para la sobrevivencia del periódico en el competitivo mercado de la información.

Cabe señalar que el método utilizado para analizar las caricaturas incluidas en las páginas que vienen a continuación, está basado en las ideas de la Escuela de Warburg, de la cual fueron partícipes historiadores del arte tales como Aby Warburg, Erwin Panofsky, Fritz Saxl, Edgard Wing y Ernst H. Gombrich, elaboradas en Londres (Inglaterra) durante la primera mitad del siglo XX. (Val, 2010: 64 - 65). En esta ocasión se utilizaran especialmente los postulados de Panofsky plasmados en su obra El significado de las artes visuales (Panofsky, 1983: 45 - 75), complementadas por ideas del historiador inglés Peter Burke señaladas en su libro Visto y no visto. El uso de la imagen como documento histórico. En resumen, se trata de la descripción de las imágenes (iconografía), como lo sugirió Panofsky en 1939, distinguiendo tres niveles de significado en cada obra. El primero de ellos está relacionado con la 
denominada "descripción preiconográfica", referida al "significado natural" de los elementos incluidos en una caricatura, es decir, identificar sujetos y objetos, en el caso de este estudio autoridades, personajes, armas, estatuas y artefactos, además de situaciones específicas tales como encuentros armados. El nivel siguiente trata el estudio iconográfico en sentido estricto, entregando el "significado convencional" de las imágenes, donde se identifica y define el acontecimiento al que se refiere el dibujo para no confundirlo con otro, en esta oportunidad, la batalla de Tacna, el combate de Agua Santa o la población civil del Callao y Lima. Finalmente se procede a la interpretación iconológica, donde cada grabado es colocado en su contexto histórico y material, en búsqueda de su significado y de la orientación intrínseca del testimonio visual referida al fenómeno estudiado. (Burke, 2001: 44 - 45 y 239 - 240). Esta metodología fue elegida para la descripción y el análisis de los dibujos satíricos incluidos en las páginas siguientes, en tanto muestra cómo las obras de arte son susceptibles de varias lecturas e interpretaciones y, más importante aún, señala que la observación de éstas requiere considerar que se trata de un "producto histórico que cobra sentido en el marco de las teorías estéticas dominantes en la época" (Val, 2010: 65).

De ese modo, se podrá explorar en la imagen construida en la prensa chilena de sátira respecto de peruanos y bolivianos, dando cuenta de una de las formas de deliberación y debate producidos en la esfera pública chilena decimonónica, elemento clave en la construcción y afianzamiento de las instituciones republicanas, mientras en paralelo se desarrollaba un enfrentamiento armado contra dos naciones al unísono, donde fueron utilizados todos los recursos discursivos, retóricos y gráficos disponibles, aprovechando el formato y características de la sátira (Ibarra, 2013: 62 - 63). Todo ello en pleno desarrollo de una guerra, que se constituyó en un periodo de singular importancia en la consolidación del Estado Nacional chileno, tanto por el fortalecimiento de sus organismos de gestión pública y la expansión territorial, y asociado a este último punto, por la adquisición de recursos naturales (salitre y cobre principalmente) que serían esenciales para el desarrollo futuro del país, como también la consolidación de la identidad moderna de los chilenos. (Subercaseaux, 2007: 197 - 203).

\section{Las caricaturas y los enemigos de Chile durante la Guerra del Pacífico.}

Desde su aparición, las caricaturas se constituyeron en un eficaz formato de difusión de puntos de vista y de tentativa por influir en la opinión pública. Cada grabado satírico implica una aguda reflexión respecto del acontecer de la sociedad, pues enseña al observador de la obra la posición y percepción del autor respecto de los hechos graficados, generalmente relacionados con el quehacer público. Del mismo modo, en esencia, los dibujos de humor político eran, y continúan siendo, un instrumento militante y de batalla, al abanderizarse a favor o en contra de personas, instituciones o ideologías. (Guerrero, 1996: 148 - 149). En general, desde su irrupción en Chile en 1858 con El Correo Literario y durante el resto del siglo XIX, los periódicos 
chilenos que incluyeron caricaturas adscribieron a los ideales y valores de la modernidad política, materializada en el liberalismo republicano, a su vez influenciado por las ideas de las revoluciones francesa de 1830 y 1848, donde se incorporó lenta pero inexorablemente al pueblo, en el lenguaje y simbolismo en la querella pública. Hacia mediados de la década de 1870, y especialmente la de 1880, su expresión visual y escrita se tornó cada vez más corrosiva, vilipendiando a personas e instituciones. (Zaldívar, 2004: 139 - 187, Cornejo, 2006b: 7 - 8 y Salinas, 2006: 235). Así es como, décadas de práctica en la batalla con pinceles y tintas en el ámbito de la política interna, fueron puestas al servicio de la causa de Chile durante la Guerra del Pacífico, reproduciendo su espíritu crítico acerbo contra peruanos y bolivianos.

La prensa de sátira contemporánea a la Guerra del Pacífico, al igual que la de noticias, poseía una opinión respecto del diario acontecer y se abanderizó ideológicamente, planteando su propio punto de vista y demandas específicas respecto de los temas relacionados con la administración del Estado en general y los relativos al conflicto en particular. De la misma manera, no perseguía el prurito de la imparcialidad al presentar los hechos. (Ossandon, 1998: 26 - 27). En ese contexto, las materias tratadas a través de las caricaturas contemporáneas al conflicto de 1879 fueron variadas. Las hubo dedicadas a la conducción política y militar, las victorias chilenas, las consecuencias para los veteranos y la visión de los enemigos de Chile, entre otras. En ocasiones, las imágenes eran apoyadas por un verso escrito en chunga, donde se relataba la situación presentada reforzando así el mensaje que se pretendía transmitir en una imagen. No obstante, la guerra no monopolizó la temática de sus grabados o escritos, pues siempre hubo un espacio, cada vez más importante en la medida que la balanza de la campaña militar se inclinó a favor de Chile, para tratar las luchas partidistas de la época, así fuera la intervención electoral propiciada desde el poder ejecutivo o la lucha por secularización del Estado, y otros temas significativos del período (Ibarra, 2013: 63).

Cabe señalar que pese a tratarse de un discurso visual que tuvo características de hegemónico y transversal en la sociedad chilena, el impacto e interpretación individual de las caricaturas quedaba supeditado a la posibilidad del receptor de la imagen a acceder de manera comprensiva a su mensaje, es decir, de su capacidad de decodificar los elementos presentes en el grabado en función de su acervo de conocimientos y actitudes que respecto del particular poseía una persona determinada. De la misma manera, por tratarse de un discurso que tenía una marcada carga ideológica, la exégesis no era posible de fuera de su contexto temporal, espacial, sociocultural, político y sus condiciones de enunciación (Méndez, 2013: 58). 


\section{Los aliados Perú-bolivianos en los periódicos chilenos de caricaturas durante la Guerra del Pacífico}

Merced a las posibilidades discursivas y estéticas de la caricatura, la prensa de sátira chilena planteó la dicotomía metafórica del roto (Chile) versus el cholo (Perú) y el cuico (Bolivia), acudiendo a imágenes estereotipadas para representar a ambos, especialmente a los peruanos. Así, en todo cuanto los chilenos eran presentados como ejemplo de valentía y valor en el campo de batalla, a los aliados se les mostró como modelo de debilidad y, por sobre todo falta de coraje ante los chilenos, todo ello a través del lenguaje burlón y mordaz propio de los dibujos satíricos.

Así, con la guerra ya en marcha el rotativo santiaguino El Barbero autodenominado como un "Periódico semanal, de buen humor, caricaturero y libre hablador", (El Barbero, 18-10-1879) ocupó sus páginas para burlarse de peruanos y bolivianos. El 15 de noviembre de 1879, casi a dos semanas de iniciada la invasión chilena a la rica provincia salitrera de Tarapacá y con dos victorias militares a su haber (Desembarco de Pisagua y combate de Pampa Germania), publicó un grabado donde se muestra como el presidente del Perú Mariano Ignacio Prado enseña el "Paso de Vencedores", a sus tropas ante la presencia de los chilenos. La escena, donde los soldados peruanos marchan rápidamente en retirada y en actitud de cubrirse, es observada por el general en jefe chileno Erasmo Escala y sus oficiales. Según el dibujante, los peruanos con su mandatario a la cabeza, huyen raudamente del campo de batalla ante sólo la estampa de Escala, dejando además a su paso todo su armamento. (El Barbero, 15-11-1879) (Fig. 1).

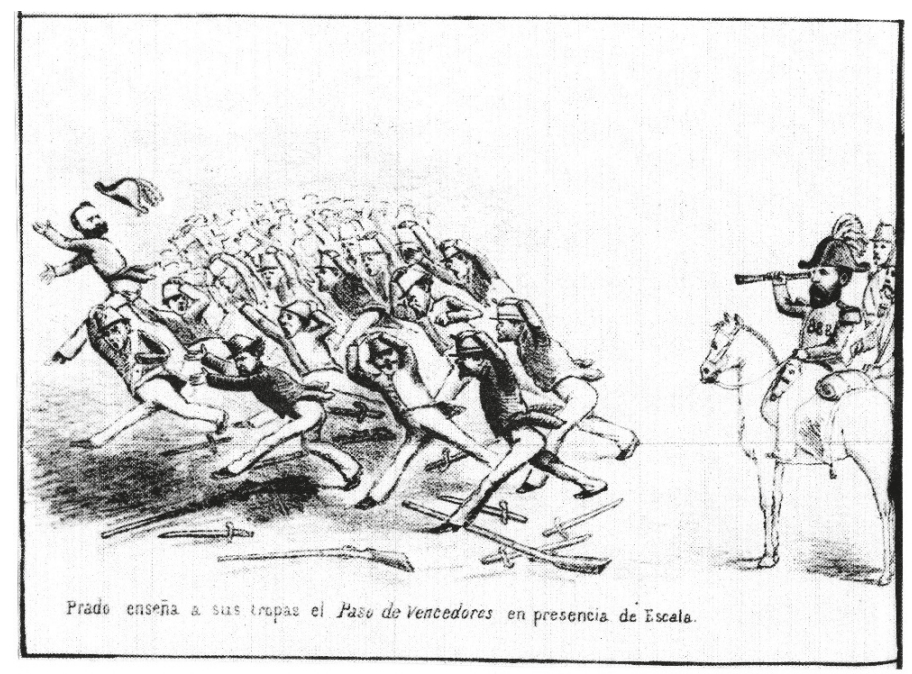

Fig. 1. El Barbero, 15-11-1879.

Así, en la mirada del periódico, a poco de iniciada la campaña Tarapacá y a la fecha sólo habiéndose registrado un combate terrestre de importancia, los aliados reconocían la superioridad de los chilenos y comprendían que el enfrentamiento con ellos 
era inútil, pues se exponían a una muerte segura y por lo tanto era preferible huir ante su sola presencia. Aquello estaba alejado de la realidad, pues los chilenos debieron superar una enconada resistencia aliada en Pisagua durante el desembarco allí efectuado ( 2 de noviembre de 1879), sufriendo 58 muertos y 173 heridos (Bulnes, 1911: 560). Del mismo modo, se utilizó la figura del primer mandatario peruano usándolo como símbolo del proceder y la poca valía de los hombres públicos de su país.

Del mismo modo, el 22 de noviembre de 1879, El Barbero dio a la luz una caricatura de humor negro donde aludió a lo sucedido en las arenas de Agua Santa (Germania), al interior de Tarapacá, donde el 6 de noviembre de 1879 un escuadrón de caballería chilena comandada por José Francisco Vergara derrotó a uno Perú boliviano. Según los partes oficiales se contaron entre los jinetes aliados 60 muertos y tan sólo 8 prisioneros, de un total aproximado de 90 efectivos. (Bulnes, 1911: 573). Por su parte, los chilenos solo tuvieron tres bajas. El dibujo se mofó de lo ocurrido, deslizando que los caídos no eran tales, sino soldados simulando estar sin vida única y exclusivamente para no enfrentar a los chilenos. La leyenda del grabado aseguró que en la oportunidad "Todos los aliados se hacen los muertos". (El Barbero, 22-111879). (Fig. 2).

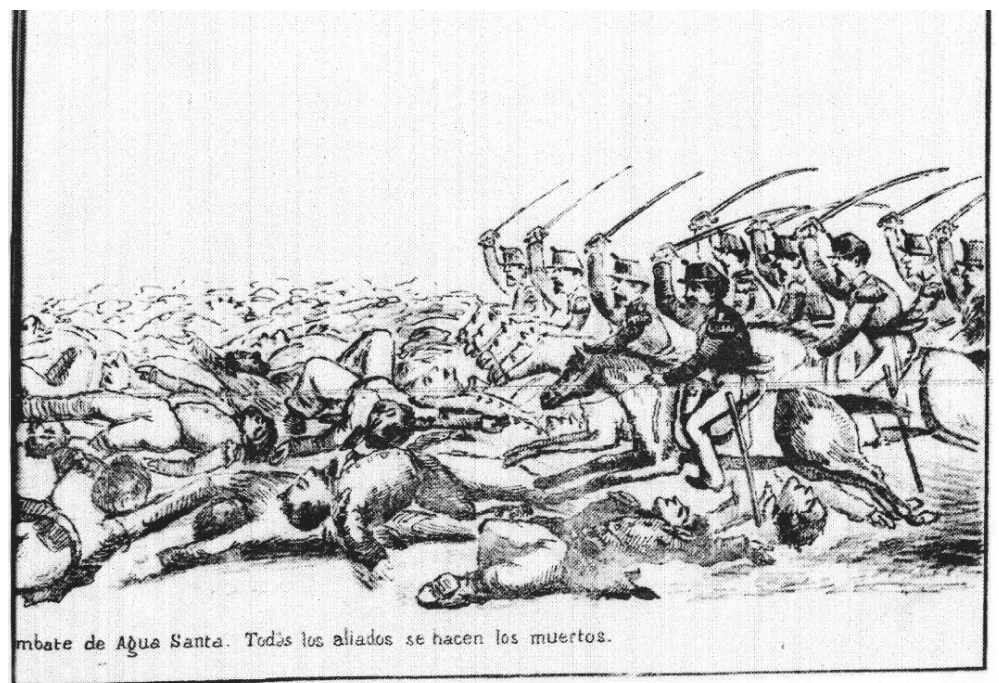

Fig. 2. El Barbero, 22-11-1879.

De esa manera, el rotativo aseguró que "hacerse los muertos" era la estrategia utilizada por los enemigos de Chile, con el objeto de evitar el combate o bien para luego atacar a los chilenos a traición. En efecto, la caricatura pudo hacer alusión al relato de un corresponsal de guerra chileno que tras el desembarco de Pisagua (2 de noviembre de 1879), conversó con un soldado del batallón Atacama pues le llamó la atención el escaso número de prisioneros aliados tomados en la acción. El infante le contestó que les había sido necesario rematar a muchos peruanos y bolivianos que habían quedado 
en la ribera "porque muchos se hacían los muertos y después les disparaban por detrás a mansalva". (Ahumada II, 1885: 91).

Por su parte, El Nuevo Ferrocarril, editado por Francisco Frías, fue un rotativo que mezcló la información con las caricaturas, ilustraciones personajes de actualidad y los hechos del diario acontecer al estilo de algunos de sus símiles europeos. Con la fase de la guerra naval terminada y la terrestre en marcha, el 17 de noviembre de 1879 , publicó en su portada una serie de grabados entre los cuales se contaba una en la cual satirizó con la estatua que en el Perú debería construirse para honrar al almirante Miguel Grau, muerto bajo las balas chilenas en el combate naval de Angamos (8 de octubre de 1879), donde fue capturado el monitor Huáscar, que tras la pérdida de la fragata blindada Independencia en Punta Gruesa (21 de mayo de 1879), se convirtió en la columna vertebral de la Marina de Guerra peruana y único buque en condiciones de incursionar contra los intereses chilenos en el océano Pacífico. El grabado ironizó con la valentía Grau, señalando que el monumento más apropiado para honrarle era la figura de un jinete de carreras de caballos. La inscripción diría: "La patria al primer jockey del Pacífico", en alusión a la estrategia utilizada por Grau entre fines de mayo y octubre de 1879, consistente en dar furtivos golpes de mano contra naves y puertos chilenos, eludiendo el enfrentamiento con los blindados Cochrane y Blanco Encalada, escapando a toda velocidad de ellos cuando se los encontró. En definitiva, el grabado se mofa de la supuesta cobardía del marino peruano, al no querer enfrentarse a los chilenos materializada en la imagen ecuestre señalada. (El Nuevo Ferrocarril, 17-11-1879) (Fig. 3).

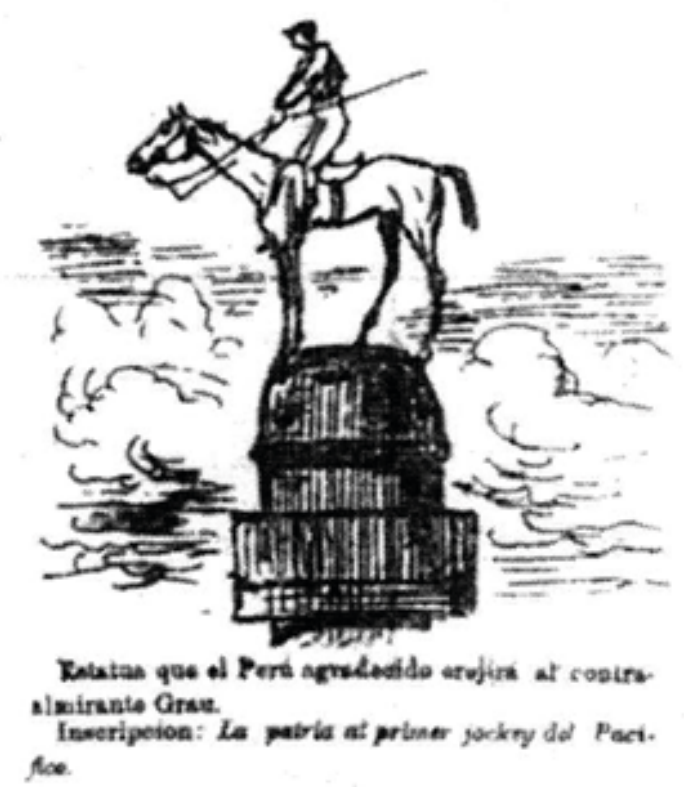

Figura 3. El Nuevo Ferrocarril, 17-11-1879. 
La ilustración era ofensiva con el Perú en dos sentidos. En primer lugar, al insistir en la idea relacionada con que los peruanos rehuían permanentemente el combate con los chilenos, y del mismo modo, al menospreciar la figura de Grau, personaje que prontamente ingresó al panteón de los héroes republicanos peruanos. Empero, la interpretación del actuar de Grau, no era transversal entre los chilenos por cuanto el corresponsal de guerra de El Mercurio de Valparaíso, Eloy Caviedes, señaló en una de sus crónicas que "la muerte de este jefe ha sido unánimemente lamentada por jefes y oficiales de nuestra marina" y agregó que "este sentimiento ha sido aqui compartido por todos, civiles y militares". (El Mercurio, 18-10-1879).

Por su parte, El Ferrocarrilito, cuya primera época fue editada en Santiago entre 1880 y 1881, fue el primer periódico de caricaturas donde participó Juan Rafael Allende, individualizado en páginas precedentes, durante los años de la guerra. Era un rotativo de batalla que se caracterizó por un discurso visual y escrito particularmente ácido para con quienes eran el objetivo de sus sátiras. Sus ilustraciones eran poco elaboradas y en ocasiones grotescas, merced a ello las caracterizaciones de los enemigos de Chile, uno de sus blancos favoritos, resultaban más punzantes y burlescas que las de otros periódicos. Así es como el 23 de junio de 1880, dio a la luz un grabado protagonizado por el contralmirante peruano Lizardo Montero, a la sazón Jefe de los departamentos del sur peruano y futuro presidente de su país (1881 - 1883), huyendo a Lima, la capital del Perú, a través del cableado telegráfico luego de participar de la derrota aliada en la batalla de Campo de Alianza (26 de mayo de 1880). (Fig. 4). El verso que acompaña el grabado señaló:

"Después de Tacna Montero, Se halló en conflictos fatales Para salvar de sus reales Poniendo en fuga el primero.

-¿Por dónde, pues, huiré yo?

Dijo asustado Montero, ¡Ah! Que friegue Campero Ya que Chile me fregó!

Y al telégrafo altanero Se asió con dientes y pies, Y por él dijo: - Adiós pues, Patitas para que os quiero."

(El Ferrocarrilito 23-06-1880). 


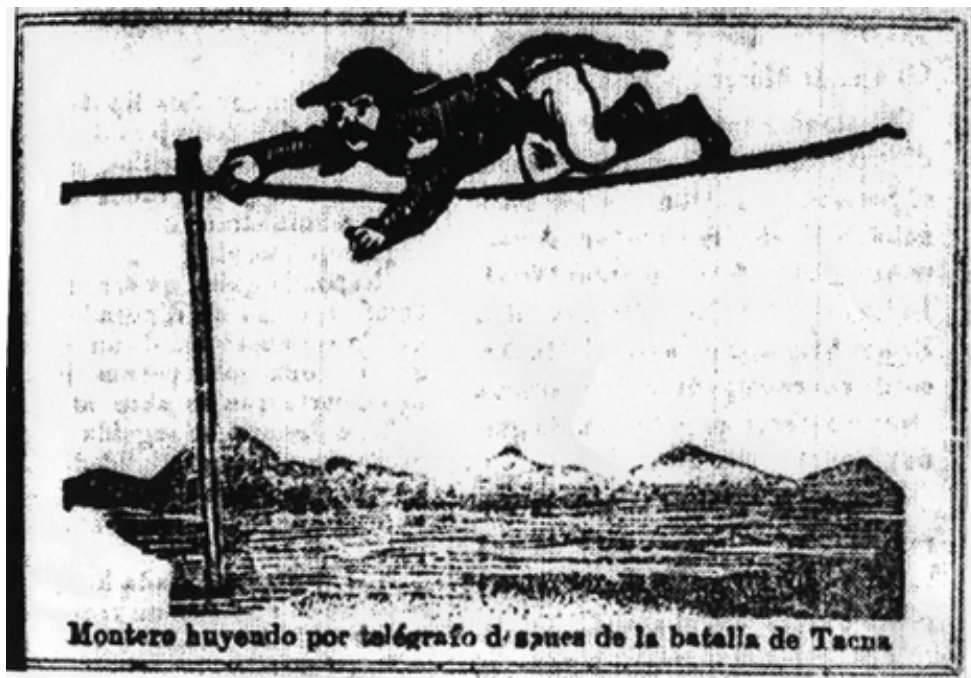

Fig. 4. El Ferrocarrilito, 23-06-1880.

En esta oportunidad, la caricatura, denostó a uno de los líderes militares peruanos, asegurando que no solo huyó ante la presencia de los chilenos, sino que también dejó a su suerte al general boliviano Narciso Campero, jefe de las fuerzas Perú-bolivianas en Tacna, para no sufrir la derrota ante los chilenos. De la misma manera, denunció la existencia solo nominal de la alianza, en tanto no existía una colaboración efectiva necesaria entre peruanos y bolivianos. El tiempo le dio la razón al periódico, pues tras el 26 de mayo terminó la cooperación efectiva de los enemigos de Chile, quedando sólo el Perú en el esfuerzo bélico.

De la misma manera, El Ferrocarrilito publicó en su portada del 9 de mayo de 1880, un grabado donde ironizó respecto de cómo la población del Callao, primer puerto peruano, reaccionó ante su bloqueo y el asedio artillero contra sus fuertes e instalaciones por parte de los chilenos (abril - octubre de 1880). La imagen reproduce a uno de los habitantes del puerto portando en su espalda algunos de sus bártulos, yéndose a Lima para resguardar su integridad. La leyenda de la ilustración alude a "los cholos huyendo del bombardeo" (Fig. 5). Acompañó a este dibujo un verso del "Redactor núm. 7", que en sus estrofas impreca con dureza a los chalacos por abandonar su lugar de residencia:

"Los cholos huyen a Lima,

Por causa del bombardeo

Llevando a la espalda, encima,

Cuanto les viene al deseo.

Se llevan cuanto encontraron

Cuanto el miedo exigió,

Solamente olvidaron

La madre que los parió. 


\section{$(\ldots)$}

Arranquen, cholos bribones,

Que los pilla el bombardeo...

Bajándose los calzones

Parece que ya los veo".

(El Ferrocarrilito, 09-05-1880).

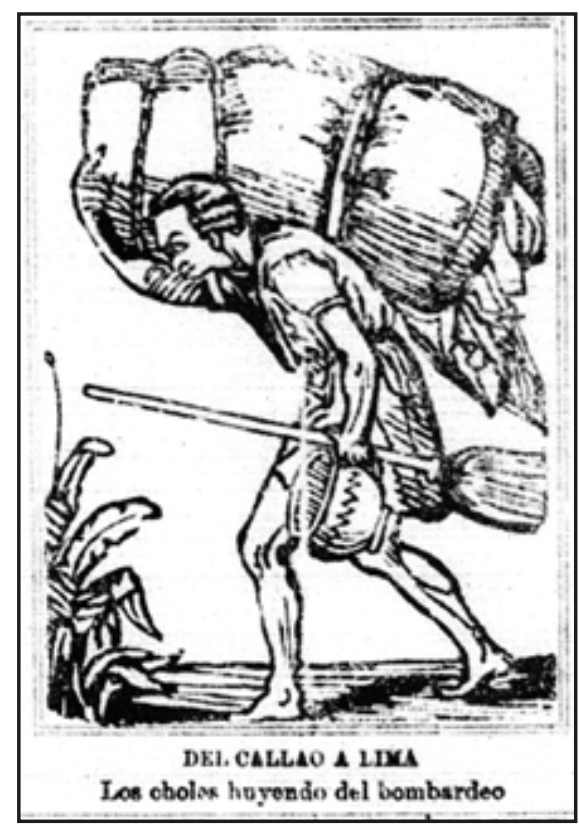

Fig. 5. E1 Ferrocarrilito, 09-05-1880.

En este grabado se alude a la falta de valor de la población común y corriente del Perú, a diferencia de las ilustraciones anteriores donde eran los dirigentes y militares quienes no deseaban enfrentar a los chilenos.

De la misma manera, el 21 de noviembre de 1880, semanas antes de producirse el zarpe la flota que condujo al ejército chileno que ocuparía Lima, El Ferrocarrilito publicó una sátira donde se muestra a un paisano, moviéndose de manera sigilosa escondiéndose para no ser enrolado en la milicia peruana y así no participar de los combates que vienen, debido al temor provocado por la inminente invasión de los chilenos y la idea de enfrentarse a ellos en el campo de batalla. (Fig. 6) (El Ferrocarrilito, 21-11-1880).

A diferencia de los grabados anteriores, en los dos últimas imágenes el protagonista de la acción era el bajo pueblo del Perú, personificado en el cholo que huye de los bombardeos chilenos y que agazapado se desliza en la oscuridad para no ser enrolado. Así, la carencia de valor, y en definitiva de patriotismo, ante la presencia de 
los chilenos, no solo es característica de los gobernantes, líderes militares y efectivos de los ejércitos aliados, sino también una característica transversal de toda la población enemiga, y muy en especial, de la peruana que habría recibir el embate de los chilenos en las afueras de Lima y ser testigos directos de como los invasores de su terruño entrarían victoriosos a su capital (Enero de 1881).

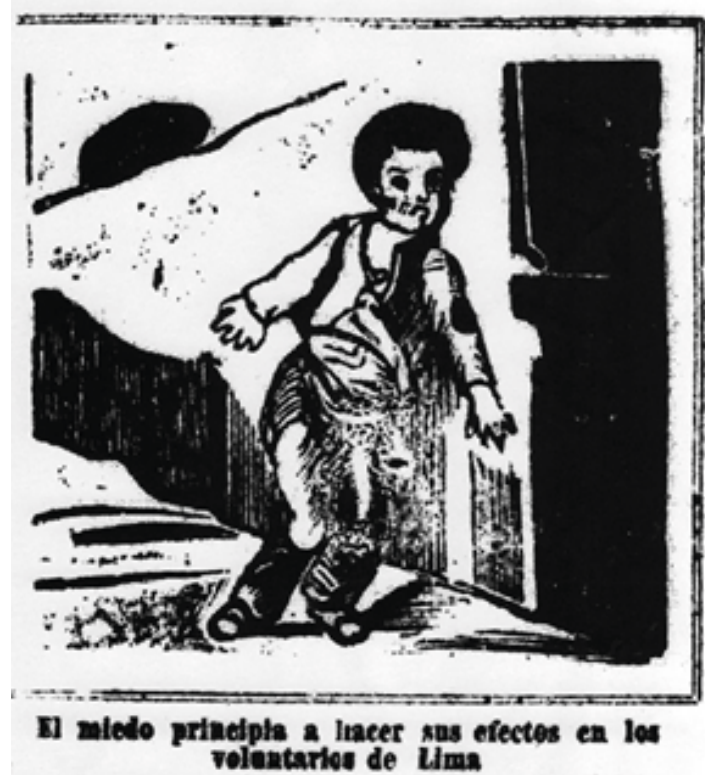

Fig. 6. El Ferrocarrilito, 21-11-1880.

Por su parte, El Padre Cobos, uno de los más importantes periódicos de caricaturas del último cuarto del siglo XIX, también editado por Juan Rafael Allende, sostuvo una línea editorial vinculada con el liberalismo, el anticlericalismo y la defensa de los derechos de los ciudadanos ante lo que consideraba la acción abusiva de la oligarquía y el Poder Ejecutivo en múltiples materias. En sus ilustraciones siempre se encontraban presentes dos personajes: "El Padre Cobos", personificación del rotativo, además de su sacristán y fiel compañero de aventuras, "El Negro". Ambos eran protagonistas de la acción presentada en las caricaturas, interactuando de diversas maneras con los personajes públicos representados en los grabados.

El 21 de octubre de 1882, El Padre Cobos celebró con el dibujo intitulado "Así se pega!" la muerte del guerrillero peruano Gregorio Abarracín, en Torata a comienzos del mes de octubre de 1882, a manos de un piquete de caballería chilena comandada por un capitán de apellido Matta. Según reza el verso que acompaña el grabado, con su triunfo Matta escribió su propia Eneida, en alusión a la epopeya latina escrita por Virgilio en el sigo I antes de Cristo por encargo del emperador Romano Augusto. También señaló que con la desaparición del montonero peruano quedó vengada la celada en el pueblo moqueguano de Locumba, organizada por el propio Albarracín y 
el sacerdote local, que en marzo de 1880 sorprendió usando "táctica mujeriega", es decir, asociando arbitrariamente a lo femenino la cobardía y felonía, a una columna comandada por el oficial chileno Diego Dublé Almeyda capturando, hiriendo y matando a algunos de sus hombres. "El Padre Cobos" y su compañero "El Negro" observan la decapitación de Albarracín, mientras que el primero porta una corona de laureles como símbolo de reconocimiento al líder de la columna vencedora. Mientras tanto, al fondo de la escena se observa como los jinetes peruanos huyen de los chilenos. (El Padre Cobos, Santiago, 21-10-1882) (Fig. 7). Un fragmento de la rima que acompañó la escena señaló:

“¡Bravo, capitán! Tu Eneida

Ya con tu espada han escrito,

Y al moler a ese parcito,

Vengamos a Dublé Almeyda.

$\mathrm{Tu}$ golpe fue tan certero,

Que dividiste en la siega

Con el mandoble primero

A caballo y caballero...

Así se pega!...

El pololo sempiterno

Y su vástago o apoyo

Han ido a parar al hoyo

Más profundo del infierno.

No volverán, no jamás

Con táctica mujeriega,

A amolarnos compás,

Que hoy les grita Satanás:

Así se pega!..."

(El Padre Cobos, Santiago, 21-10-1882).

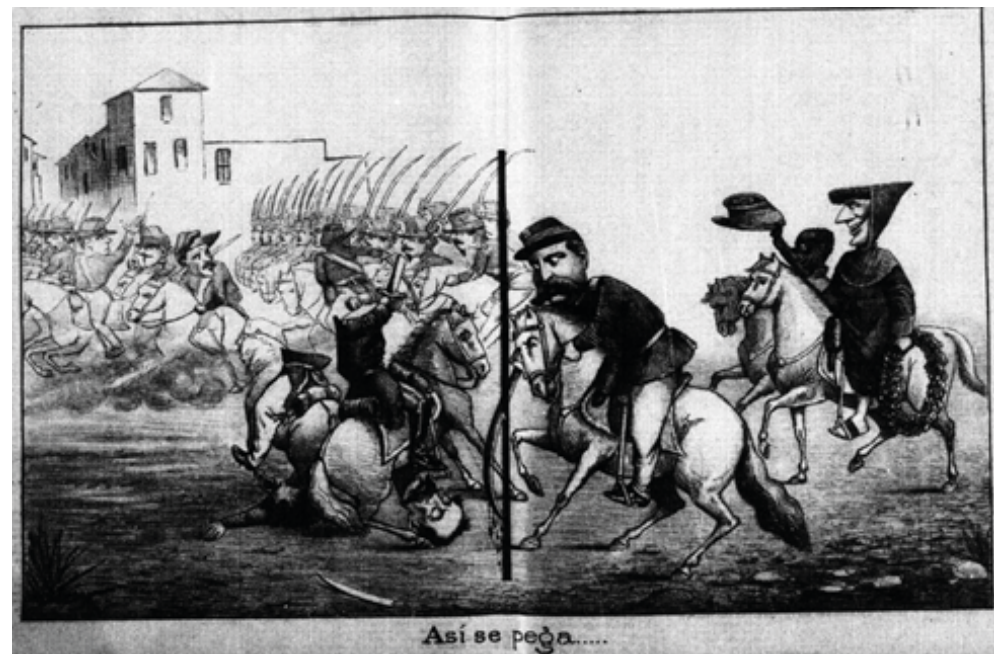

Fig. 7. El Padre Cobos, 21-10-1882 
De la misma manera El Padre Cobos ironizó con la llegada de las tropas chilenas encabezadas por el coronel José Velázquez a Arequipa en septiembre de 1883. Esta fuerza fue enviada con objeto de neutralizar las tropas y montoneras que operaban al interior del Perú, poniendo en riesgo la estabilidad del gobierno del general peruano Miguel Iglesias con quien los chilenos habían alcanzado un acuerdo de paz. De ese modo, las autoridades de ocupación determinaron la necesidad de realizar una expedición militar sobre Arequipa y sus alrededores, sede del autoproclamado gobierno del almirante Lizardo Montero. El Padre Cobos publicó la caricatura intitulada "Recepción del General Pililo en Arequipa" el día 6 de octubre de 1883, en la cual se muestra a las fuerzas peruanas arequipeñas huyendo ante la sola presencia del general Pililo, figura metafórica acuñada durante los años de guerra que representó a los rotos y por extensión a las tropas chilenas. (Fig. 8) (El Padre Cobos, 06-10-1883).

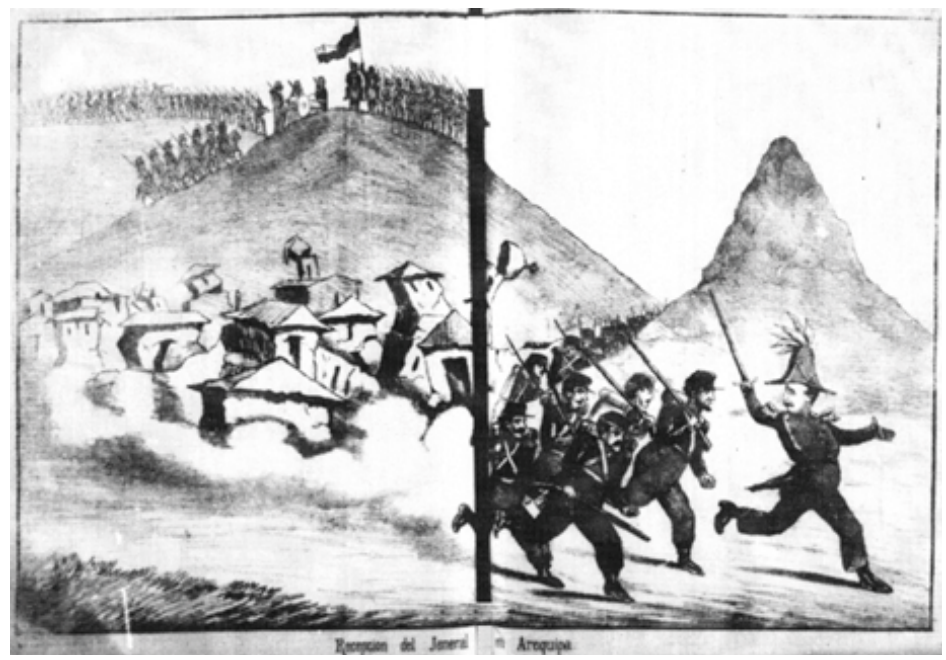

Fig. 8. El Padre Cobos, 06-10-1883.

El verso que acompañó la escena, una conversación entre Velázquez y "El Padre Cobos", señaló que los edificios se inclinan, el volcán Misti vecino a la ciudad apagó sus fuegos $\mathrm{y}$, más importante aún los arequipeños huyen ante la presencia de los chilenos:

“- Mire, Padre, con qué gusto

Arequipa nos saluda...

Como tiembla y como suda...

-Termínese la conquista!

Nada a nuestra gloria falta...

Hasta la torre más alta

Se doblega a nuestra vista...

- ¿Y el Misti, que amenazaba

Abrazarnos con su fuego?

Sus fuegos apagó luego, 
Se tragó toda su lava...

¿Y el invencible almirante

De agua dulce? ¿Dónde está?

-Allá Padre, allá va

El grandísimo tunante!

Déjeme largarle un tiro...

-Eh! La muerte no merece,

$\mathrm{Y}$ tal vuela que parece

Un volador de suspiro...

¿Y sus cholos? Llevan alas

Como Mercurio en sus pies...

Pillarlos posible no es,

Pues corren más que las balas

-Si todos en confusión

Escapan al acercarnos

¿Con quién vamos a chopearnos?

¡Espléndida recepción!

-Mejor. El pueblo tranquilo

Tomaremos fácilmente

-¡Así recibe esta gente

Al gran General Pililo!"

Al igual que en imágenes anteriores, la caricatura y el verso, consideran tanto a gobernantes como a la población peruana, además de las edificaciones y la naturaleza, incapaces de hacer frente a los invasores de su territorio, prefiriendo rehuir la lucha sin siquiera intentar resistir.

\section{Conclusión}

Mientras miles de hombres combatían en los campos de batalla de la Guerra del Pacífico, en las redacciones de los periódicos de sátira, escritores, poetas y dibujantes chilenos blandieron sus afilados lápices y pinceles para combatir a su manera a sus adversarios. En su caso, lo hicieron creando figuras estereotipadas de ellos.

Las caricaturas publicadas en los periódicos chilenos de sátira durante los años de la guerra, 1879 - 1884, se constituyen como una fuente que facilita dar una mirada distinta a un conflicto muchas veces estudiado desde diversas perspectivas. Así también, permiten caracterizar como fue el comportamiento de los periódicos de sátira chilenos, como parte del medio de comunicación masivo por excelencia del siglo XIX. En ese sentido, la prensa jugó un importante rol como vehículo interpretativo respecto de la contingencia bélica, colocándose al servicio de la causa nacional, señalando de ese modo la trascendencia del estudio del comportamiento de los rotativos al momento de cubrir, desde diversas perspectivas y formatos, las alternativas de un enfrentamiento armado de grandes proporciones. 
De la misma manera, cabe señalar que la elaboración de dibujos satíricos fue otra manera de documentar el conflicto. Merced a su naturaleza, gráfica y lúdica, permiten un acercamiento a cómo se pensó, interpretó, representó y proyectó una fracción de las ideas que se encontraban en discusión en la esfera pública contemporánea, respecto de un fenómeno de gran trascendencia para los países involucrados, no solo por la coyuntura bélica, sino por lo que implicó para su desarrollo institucional, político, económico y cultural futuro.

Una de las ideas que circularon por la esfera pública chilena durante el conflicto del Pacífico, fue el cómo se valoró y representó a los aliados Perú - bolivianos, la cual se mediatizó a través del lenguaje visual de la caricatura. Concordante con la línea editorial de la prensa chilena de noticias, que vilipendió sin tapujos a peruanos y bolivianos durante los años del conflicto, la de humor escrito y gráfico también colaboró al descrédito de los enemigos de Chile presentándolos siempre en un plano de diferenciación respecto los suyos. De ese modo, construyeron un "otro" a partir de su difamación, anclándose en el rescate y construcción simbólica negativa del adversario a derrotar. El discurso visual transversal de los rotativos de humor gráfico, se planteó de forma crítica creando una imagen a partir de la subjetividad propia de la burla.

Una de las ideas desplegadas en los periódicos que incluyeron humor gráfico, fue la relacionada con que la sola presencia de las tropas chilenas bastaba para poner en fuga a sus símiles aliados. Aquello fue sólo una exageración por parte de dibujantes y editores de los medios, por cuanto, pese a las sucesivas victorias de las armas chilenas a lo largo del conflicto, estas fueron conseguidas tras grandes esfuerzos y a un importante coste de bajas. El mensaje de las imágenes, reforzado en oportunidades con la inclusión de versos, resaltaba la inferioridad de los enemigos de Chile y trasuntó la debilidad de las convicciones y compromiso nacional de los aliados.

Peruanos y bolivianos, sin distinción de clase o sexo, fueron presentados como carentes de valor. Aquello colaboró para la creación y consolidación de un estereotipo repetido y persistente en el tiempo, fundamentado en las sucesivas victorias de los chilenos y fortalecido tras el triunfo final en la guerra. Así fue como, ideas largamente asentadas en el tiempo y en el éxito militar, dieron paso a la creación de un canon de apreciación de sus vecinos del norte. Esa fue la idea fuerza desplegada en esos escritos y caricaturas. De ese modo, colaboraron en la construcción de un estereotipo de los enemigos de Chile, el cual resultó provechoso para la unificación del discurso e imaginario patriótico - nacionalista, con miras a robustecer la unión simbólica y fáctica de los chilenos, en torno a la consecución de la victoria guerra de 1879 .

Los periódicos construyeron la imagen de los enemigos de Chile aprovechando las posibilidades discursivas y estéticas de la caricatura. Presentaron la supuesta cobardía de peruanos y bolivianos, utilizando para ello diversas imágenes, a saber, jinetes de carrera, muertos simulados, sujetos temerosos, $y$, en especial, tropas que huyen ante la presencia de los chilenos. En todos los periódicos se desplegó un humor corrosivo, desde la comicidad negra de El Barbero y El Padre Cobos, pasando por la burla 
e insultos descarnados de El Ferrocarrilito, hasta la comicidad más simple, pero igual de punzante, de El Nuevo Ferrocarril. Así, todos pregonaron con entusiasmo la guerra y se mofaron sin miramientos de los aliados.

En definitiva, la prensa en general y la de humor en particular, abrazaron la causa chilena y, a través de sus afilados lápices hicieron lo suyo para enaltecer a los chilenos y vituperar a los aliados Perú-bolivianos, durante los años que duró el conflicto que enfrentó a tres estados nacionales por la posesión de los ricos territorios salitreros de Antofagasta y Tarapacá.

\section{Referencias bibliográficas}

Periódicos

El Barbero (Santiago, 1879)

El Ferrocarrilito (Santiago, 1879 - 1880)

El Fígaro (Santiago, 1879)

El Nuevo Ferrocarril (Santiago, 1879)

El Mercurio (Valparaíso, 1879)

El Padre Cobos (Santiago, 1881 - 1883)

Libros y artículos

AHUMADA, P. (1885). Guerra del Pacífico. Recopilación completa de todos los documentos oficiales, correspondencias y demás publicaciones referentes a la guerra que ha dado a la luz la prensa de Chile, Perú i Bolivia. Conteniendo documentos de importancia. 8 Vols. Valparaíso: Imprenta i Lib. Americana de Federico T. Lathrop.

ARELlanO, J. (2012). "Discursos racistas en Chile y Perú durante la Guerra del Pacífico". En: Estudos Ibero - Americanos, 38, 2, Porto Alegre: p. 239 - 264.

ARELLANO, J. (2014). "La Guerra del Pacífico y el americanismo republicano en el discurso bélico peruano", História Unisinos, 18, 2, Sao Leopoldo: p. 392 - 402. BHABHA, H. (2002). El lugar de la cultura. Buenos Aires: Manantial.

BRISEÑO, R. (1885). Cuadro sinóptico periodístico completo de los diarios y periódicos en Chile publicados desde 1812 hasta el año de 1884. (Redición computarizada en nuevas tablas y con gráficos agregados por MARTÍNEZ, G.; Colle, R. (1987). Pontificia Santiago: Universidad Católica de Chile, Facultad de Letras).

BULNES, G. (1911-1919). Guerra del Pacífico. 3 Vols. Valparaíso: Sociedad Imprenta y Litografía Universo.

BURKE, P. (2001). Visto y no visto. El uso de la imagen como documento histórico. Barcelona: Crítica. 
CID, G. (2009). "Un icono funcional: la invención del roto como símbolo nacional. 1870 - 1888". En CID, G. - SAN FRANCISCO, A. (eds.). Nación y nacionalismo en Chile. S. XIX, Vol. 1, Santiago: Centro de Estudios Bicentenario. p. 221 - 254.

COLLIER, S. (2005). Chile. La construcción de una república. 1830 - 1865. Política e ideas. Santiago: Ediciones Universidad Católica de Chile.

CORNEJO, J. (2006). "La República como mujer en los periódicos de Juan Rafael Allende: un discurso político en caricaturas". En: Mapocho, ${ }^{\circ}$ 59, Santiago: p. $11-46$.

CORNEJO, T. (2006). "La injuria en imágenes: el vilipendiado honor de los hombres públicos en la prensa satírica (1860 - 1900)". En: Nuevo Mundo Mundos Nuevos [En línea]. Coloquios, Puesto en línea el 15 de septiembre 2006, consultado el 23 enero 2014. http://nuevomundo.revues.org/2815;DOI:10.4000/nuevomundo.2815

CRUZ DE AMENABAR, I. (1996). "Diosas atribuladas: alegorías cívicas, caricatura y política en Chile durante el siglo XIX", En: Historia, Vol. 30, Santiago: p. 127-171.

DONOSO, C.; HUIDOBRO, M. (2015). "La patria en escena: el teatro chileno en la Guerra del Pacífico", En: Historia, n 48, Vol. I, enero - junio, Santiago: p. 77 - 97.

DONOSO, R. (1950). La sátira Política en Chile, Santiago: Imprenta Universitaria.

GIMATE - WELSH, A. "La representación de la caricatura política: la pugna Madrazo - Gordillo en el PRI”. En: Revista LIS - Letra Imagen Sonido, Año III - IV \# 6 - 7 , p. $57-70$.

GUERRERO Y., C. (1996). "Los capitanes de la industria a través de las caricaturas contemporáneas, 1870 - 1920”. En: Cuadernos de Historia, ${ }^{\circ}$ 16, Santiago: $\mathrm{p}$. $133-171$.

IBARRA, P. (2014). "Liberalismo y prensa: Leyes de imprenta en el Chile decimonónico (1812-1872)". En: Revista de Estudios Histórico Jurídicos, n 36 . Valparaíso: p. $293-313$.

IBARRA, P. (2013). "Veteranos y prensa satírica: desmovilizados e inválidos en los periódicos chilenos de caricaturas durante la Guerra del Pacífico (1879 - 1884)". En: Universum, 28, 2. Talca: p. 59 - 81.

LE SHAN, L. (1992). La psicología de la guerra. Un estudio de mística y su locura. Santiago: Editorial Andrés Bello.

MÉNDEZ, J. (2013). "La interpretación de la caricatura política: un asunto de cultura", En Zona próxima, $\mathrm{n}^{\circ}$ 18, enero - junio: p. 46 - 59.

MC EVOY, C. (2011). Guerreros civilizadores. Politica, sociedad y cultura en Chile durante la Guerra del Pacífico. Santiago: Ediciones Universidad Diego Portales.

OSSANDON, C. (1998). El crepúsculo de los sabios y la irrupción de los publicistas. Santiago: LOM.

PANOFSKY, E (1983). El significado en las artes visuales. Madrid, Alianza Editorial.

RUBILAR, M. (2011). "Escritos por chilenos, para los chilenos y contra los peruanos": la prensa y el periodismo durante la Guerra del Pacífico (1879 - 1883)". En DONOSO, C. y SERRANO, G. Chile y la Guerra del Pacifico. Santiago: Centro de Estudios Bicentenario. p. 39 - 74. 
SALINAS, M. et. al. (2011). El que ríe último... caricaturas y poesías en la prensa humorística chilena del siglo XIX. Santiago: Centro de Investigaciones Diego Barros Arana.

SALINAS, M. (2005). "Erotismo, humor y trasgresión en la obra satírica de Juan Rafael Allende". En Mapocho, n 57, Santiago: p. 199 - 248.

SALINAS, M. (2006). "Y no se ríen de este leso porque es dueño de millones!: El asedio cómico y popular de Juan Rafael Allende a la burguesía chilena del siglo XIX". En Historia, 39, Santiago: p. 231- 262.

SOLA, S. y BARROSO, G. (2004). "El cómic de no-ficción como fuente para el estudio de los conflictos bélicos: Crónicas de Jerusalén". En: Historia y comunicación social, Vol. 19, Madrid, Universidad Complutense de Madrid, p. 231 - 248.

SUBERCASEAUX, B. (2007). Historia de las ideas y de la cultura en Chile. Tomo IV. Nacionalismo y cultura. Santiago: Editorial Universitaria.

URETA, C. y ÁlVAREZ, P., (2014). Luis Fernando Rojas. Obra Gráfica 1875 1942, Santiago: LOM.

VAL, A. (2010). "Una aproximación metodológica en el análisis de las obras de arte". En: Arte, individuo y sociedad, 22 (2), Madrid, Universidad Complutense de Madrid. p. 63 - 72.

ZALDÍVAR, T. (2004). "El papel de los monos". Breve crónica de un tercio de siglo de prensa de caricatura 1858 - 1891". En SOTO, A. Entre tintas y plumas. Historias de la prensa chilena del Siglo XIX. Santiago: Universidad de los Andes. p. $139-178$. 